\title{
THE POLITICS OF RETALIATION:
}

\section{The Backlash of Radical Islamists} to Deradicalization Project in Indonesia

\section{Masdar Hilmy}

State Institute for Islamic Studies (IAIN) Sunan Ampel, Surabaya, Indonesia

\begin{abstract}
This paper seeks to analyze how the program of deradicalization in Indonesia is approached, understood and treated by radical Islamists. This paper argues that the deradicalization program in this country has invited controversies, criticisms and even backlash from radical Islamists on the grounds that it goes against the principles of human rights because of state's intervention into religious life of its citizens. In addition, it is carried out by violent method which mostly ends with killing the accused terrorists along with the arrest and ambush by security officers. In order to analyze the focus of the study, this paper employs socio-political approach. This paper finds that more thorough approach needs to be employed by the state within the framework of buman rights. Therefore, the ideology of radical Islamism and terrorism must be dealt with from two sides; at the upstream and the downstream levels. At the upstream level, the program of deradicalization must be carried out within the framework of interdepartmental and ministerial partnership. This program should invite as many institutions as possible to be involved and reach as wide audience as possible. At the downstream level, the program of deradicalization must abide to buman rights principles. The security approach taken by the government should not end with killing or dehumanizing terrorists. By doing so, the national program of deradicalization can appeal as wide sympathy possible and will not harvest backlash from the Islamists.
\end{abstract}

[Artikel ini mendiskusikan bagaimana program deradikalisasi di Indonesia 
dipahami, dimengerti, dan disikapi oleh kalangan Islamis. Tulisan ini berasumsi bahwa program deradikalisasi yang dilakukan memincu kontroversi, kritik, babkan memicu juga aksi balasan yang dilancarkan kalangan Islamis radikal. Beberapa kalangan menilai program tersebut melanggar prinsip hak asasi manusia karena merepresentasikan bentuk intervensi negara terhadap kehidupan beragama masyarakatnya. Lebih dari itu, beberapa program dilaksanakan dengan melakukan tindak kekerasan dan kerap berakhir dengan penangkapan, penganiayaan, babkan pembunuban tersangka teroris. Dalam menganalisis tema tulisan, pendekatan sosialpolitik digunakan. Artikel ini kemudian menemukan babwa pendekatan yang berangkat dari nilai-nilai hak asasi manusia perlu dipertegas. Karena itu, ideologi islamis-radikal and terorisme harus dilihat melalui dua sisi secara bersamaa. Pada level atas, program deradikalisasi dilakukan dengan kerjasama antar lembaga dan kementerian terkait. Dengan begitu, program deradikalisasi diwujudkan dengan mengajak sebanyak-banyaknya lembaga untuk terlibat serta memperluas target audien. Pada level bawah, program deradikalisasi harus mamatubi prinsip hak asasi manusia. Pendekatan keamanan yang dominan dilakukan tidak harus berakhir dengan membunub atau dengan melanggar hake asasi manusia yang juga melek at pada diri Islamis dan teroris. Dengan model seperti ini, program nasional deradikalisasi mampu memperoleh dukungan dan simpati masyarakat luas dan dapat meredam aksi balasan kalangan Islamis.]

Keywords: deradicalization, radical Islamism, Densus 88, BNPT

DOI: $10.14421 /$ ajis.2013.511.129-158

\section{A. Introduction}

Analyzing the reality of radical Islamism necessitates a more thorough approach in order to capture what is at work in both surface and deeper structures. This is so because the reality of radical Islamism in Indonesia is far more complex than some observers have perceived. Monolithic approach to the reality of radical Islamism can lead to more complex multiplier effects, such as misconception about the reality of radical Islamism leading to the adoption of inappropriate policies by the State to deal with the issue. This can further provoke the resistance among 
the radical Islamists to fight back against the perceived enemies—both far and close enemies - through violent acts. The destructive effects at the psychological level caused by violent and terroristic acts by the radical Islamists can be more devastating than that at the physical level. This can in turn destabilize socio-political condition of the country, the vanishing of the sense of security, the decrease in international trust to the economic investment, and the like.

It has been admitted that the State or government's policy in dealing with the ideology of radical Islamism relies heavily on security approach, neglecting the most fundamental approach, i.e. deradicalization of their radical ideology through soft approaches. The security approach proves to invite further controversies and criticisms, particularly from the Islamists' circle. The ambush followed by shooting by the special taskforce called Detasemen Khusus (Densus) 88 on the violent jihadists is considered as an inappropriate measure which in turn invites tacit sympathy from Islamists in general. The death penalty given to Bali bombing perpetrators (Imam Samudra, Imam Mukhlas, and Amrozi) has also appealed sympathy from the majority of Islamists. A lot of them regard those bombers as martyrs (shubadà) serving as a source of inspiration for the younger Islamists to launch their retaliation towards anything perceived as enemies, both near enemies such as the police and the ruling government, and far enemies, such as the US and its allies.

The tacit sympathy can even be derived from mainstream moderate organizations such as NU and Muhammadiyah that perceive the backlash of radical Islamists as representation of resistance against the US global hegemony over the Muslim world. This assumption is not without reason. Research undertaken by Erich Kolig in Surakarta (Solo) Central Java revealed a staggering fact that Muslim hardliners received tacit sympathy from moderate Muslims. ${ }^{1}$ This is further supported by the fact that there is no a clear dividing fault-line between Muslim hardliners and moderate Muslims. ${ }^{2}$ However, both parties can exchange their position and join together in one camp when necessary, particularly in the issues regarding the suffering Muslims all over the world exposed in the media, and

${ }^{1}$ Erich Kolig, "Radical Islam, Islamic Fervour, and Political Sentiments in Central Java, Indonesia," European Journal of East Asian Studies 4, No. 1 (2005), pp. 55-86.

${ }^{2}$ Masdar Hilmy, Islamism and Democracy in Indonesia: Piety and Pragmatism (Singapore: ISEAS, 20010), p. 101. 
Islamists who retaliate on the grounds of helping their fellow Muslims, considered as true jibadist.

With regard to the comprehensive effort at understanding the phenomenon of radical Islamism, what happens at the surface level often differs significantly from what is at work at the deeper level. This is so because theologically speaking, the radical Islamists do not hesitate to employ the politics of deceit or taqiyah — a religious doctrine which is in the beginning only acknowledged among the Shi'te — to hide the true religious identity. In this context, a radical Islamist will be ready to do anything, including decieving security officers, as long as this strategy will benefit him/her. Hiding the true faith is considered by his/her believed to protect theological standpoint. Moreover, showing their true identity will endanger their underground activities. Such a strategy is believed by Nasir Abbas, an ex-Jema'ah Islamiyah (JI) combatant, employed by Abu Bakar Ba'asyir throughout his trial process. ${ }^{3}$

To provide the majority of moderate Muslims with moderate theology in order to keep distant from the threat of radical Islamist ideology, in addition to deradicalizing those jihadist Islamists who had been involved in underground movements, is among the challenging homework to do in dealing with radical and terroristic Islamist ideology in Indonesia. Ideally speaking, the deradicalization attempts necessitate two big interrelated steps at once; upstream and downstream levels. At the upstream level, the deconstruction of radical ideology must be done in tandem with propagating the moderate Muslim ideology. At the downstream level, the construction of moderate theology must be disseminated into the whole segments of society, reaching not only elite class and educated people, but also those who are religiously and academically "illiterate". Inclusive of this category is radical groups and individuals as the target of such dissemination.

This paper seeks to analyze the deradicalization process and the backlash of radical Islamists in Indonesia. The theoretical assumption developed throughout this paper is that, despite the fact that the idea does matter for the Islamists, the ideologues (person factor) have played far more important role compared to that of ideology. This is so because

${ }^{3}$ Nasir Abas, Membongkear Jamaah Islamiyah: Pengakuan Mantan Anggota JI (Jakarta: Grafindo, 2005). 
it is the ideologues that have the capacity to construct the ideology of radical Islamism and convince their fellow Islamists to hold such an ideology. Assuming that the ideology matters for the Islamists means that one acknowledges the importance of Weberian approach which presupposes ideology as an embedded element exists in advance prior to such other extrinsic aspects as politics, economy and social. On the other hand, assuming that the ideology has less important role to play than that of extrinsic aspects means that one admits the significance of Marxian approach. Instead, this paper seeks to stand in the middle by arguing that ideologues have a mediating role between ideology and extrinsic aspects in making radical Islamist ideology.

\section{B. Some Features of the Ideology of Radical Islamism}

One of the most obvious features of the ideology of radical Islamism is totalitarian in character. ${ }^{4}$ As an antithesis of secular Western ideology, the ideology of radical Islamism puts more emphasis on integrative vision of Islam as a religious doctrine and social practice. Islam, according to radical ideologues, covers all aspect of life, which includes hereafter and worldly matters. This doctrine is called Islam as "3 Ds" (din, dunya, dawlah/religion, world, state) proposed by the majority of the ideologues of radical Islamists. ${ }^{5}$ It regulates not only vertical-ritualistic aspects, but also totalistic worldview guiding all aspects of life such as politics, economy, social, and culture. This culminates to the need and obligation imposed upon every adult Muslim to establish an "Islamic state", through which all regulations which are in line with the shari'ah can be imposed on every individual. ${ }^{6}$

The next feature of radical Islamism is literal approach used to read sacred texts. ' 'Literal' in this context means the tendency of

${ }^{4}$ Eric Davis, "Ideology, Social Class, and Islamic Radicalism in Modern Egypt," in Said Amir Arjomand (ed.), From Nationalism to Revolutionary Islam (London: The Macmillan Press, Ltd.,: 1984), p. 146.

${ }^{5}$ Nazih Ayubi, Political Islam: Religion and Politics in the Arab World (London: Routledge, 2004), p. 123.

${ }^{6}$ William E. Shepard, "Islam and Ideology: Towards a Typology," International Journal of Middle East Studies, Vol. 19, No. 3 (Aug., 1987), p. 308.

${ }^{7}$ Najib Ghadbian, "Political Islam and Violence," New Political Science, Vol. 22, No. 1(2000), pp. 77-88. 
radical groups to assert what is explicitly mentioned in the sacred texts such as the Qur'an and Hadith without taking historical context into account. Interpretation and rational approach to the texts is considered unnecessary as long as the texts have stated explicitly. The degree of piety is, among others, determined by the extent to which an individual Muslim has totally and literally embraced whatever instructed by the texts. On the other hand, they tend to avoid what is not mentioned in sacred texts. They will consider anything existing outside of the texts as innovation or novelty (bid'ah) which is forbidden (baram) in Islam. They further argue that such Western-derived concepts as democracy, liberalism, capitalism and the like are bid'ah, because religious texts do not explicitly mention them and, therefore haram in Islam. ${ }^{8}$

The third feature of radical Islamist ideology is symbolic religious understanding. ${ }^{9}$ In such an understanding, what is at stake is the mindset obsessed with symbolic games rather than an essence. Symbol represents a determinant variant in the mindset of radical Islamists. This affects the way the radical Islamists perceive all aspects of life; everything must be related to symbol. Democracy, for instance, symbolizes the human's revolt against the sovereignty of God; capitalism symbolizes the arrogance of Western hegemony over the rest of the world, including Islam, in economy; the US and its allies symbolizes the common enemy of Muslims; churches and other non-Muslim worshipping houses symbolize the threat to the faith of Islam; the Cross and David star symbolize the devil power of Goliath which captures and undermines the supreme Islam and Muslims; and so on and so forth.

Such a symbolic way of thinking implies the tendency of simplistic and reductionistic way of thinking. The radical simplifies the complicated reality by relating a particular fact with the other which is in fact not related to one another. This is a result of the lack of critical thinking imposed on the radical Islamists' formal training in responding whatever they see, read and experience in their life. Reductionism is characterized by mixing several things which are different in nature together into one bracket of category which are considered identical. They, for instance,

\footnotetext{
${ }^{8}$ Masdar Hilmy, Islamism and Democracy in Indonesia, p. 165.

${ }^{9}$ Brian F. Farmer, Understanding Radical Islam: Medieval Ideology in the Twentieth Century (New York: Peter Lang, 2007), p. 123.
} 
consider Judaism as identical with Israel and vice versa; Christianity is considered identical with the West; democracy, capitalism, secularism seen as similar or identical with infidelity, and so on and so forth.

The fourth feature of radical Islamist ideology, is Manichean approach to reality. ${ }^{10}$ According to the majority of Islamists, the world is divided into two spheres: right and wrong, black and white, pious and sinful, reward and punishment, allowable (halal) and forbidden (haram), and the like. This Manichean approach is particularly dominant in the area of Islamic law; either something is haram or halal. The reality is much more than as simple as that. As a result, they tend ignore the other three juridical regulations in Islam as formulated and developed by classical Muslim scholars as found in classical books in addition to haram or halal: sunnab (commendable), makrub (abominable) and mubab (allowable). ${ }^{11}$ This is because these regulations are reduced merely into two poles: right or wrong, black or white, halal or haram.

The fifth characteristic of radical Islamist ideology is narrowmindedness or closedness from external influences or ideas. Once radical Islamists hold something as true, they will hold and maintain it, until the last drop of their blood. In the discourse of political science, this ideology is identical with cultural-essentialism in which ideology is treated as a closed entity and does not subject to any change. ${ }^{12}$ The closedness of radical Islamist ideology is similar to the closedness of other totalitarian ideologies. What makes it different from the others is that radical Islamist ideology is constructed on the ground of sacred texts, while other ideologies are not. It is not surprising that radical Islamist ideology carries more authoritative sense than secular ideologies.

The sixth feature of radical Islamist ideology is purificationist in nature. ${ }^{13}$ They do not want to practice or let the others practice the version

\footnotetext{
${ }^{10}$ Emmanuel Sivan, “The Enclave Culture," in Martin E. Marty \& Scott Appleby (eds.), Fundamentalisms Comprehended (Chicago: University of Chicago Press.Sivan, 2004), p. 21.

${ }^{11}$ Martin van Bruinessen, "Genealogies of Islamic radicalism in post-Suharto Indonesia”, South East Asia Research vol. 10, no. 2 (2002); pp. 117-154.

${ }^{12}$ Sanford Lakoff, “The Reality of Muslim Exceptionalism," Journal of Democracy, Vol. 15, No. 4 (Oct 2004): pp, 133-40.

${ }^{13}$ Said Amir Arjomand (ed.), From Nationalism to Revolutionary Islam (Albany, N.Y.: State University of New York Press, 1984), p. 229.
} 
of religiosity that is considered contaminated by "un-Islamic" elements. Islamists will take into account the issues of theological authenticity contained in the doctrine and practice to preserve the purity of Islam as believed to have been practiced by their pious predecessors (al-salaf alshalib). In their understanding, on the basis of Hadith, the best Muslim generation is the three earliest generations after the Prophet Muhammad. The concept of authentic "Self" in their viewpoint comprises of the core aspect of their ideology. In this context, becoming authentic "Self" means obeying all God's commandment and distancing away from His prohibition.

What "authentic" in this context means something that has to do with values (hadlarah), and not with to the product of science and technology (madaniyah) which is allowed to adopt from any civilization, not exclusive from secular Western civilization. ${ }^{14}$ Although they have their own dress code, for instance, they subscribe the product of modern technology to make their life easier. It must be admitted that radical Islamists are technologically literate even though they are not deeply learned in religious knowledge. Therefore, it is not surprising that they are quite familiar with the product of modern technology such as computer programs, internet, cellular phones and other technological gadgets. Nevertheless, they will not drop their subscription to backward belief in Islam.

\section{Roots of Radical Islamist Ideology}

It must be admitted from the outset that there is no single monolithic theoretical framework that can explain the roots of radical Islamist ideology. It is simply because there are a number of factors contributing to the birth and development of radical ideology. Therefore, one cannot point finger to one factor that gives birth to the rise of radical Islamist ideology. In this context, this paper argues that the first factor that causes the birth and rise of radical Islamist ideology is something to do with external factors outside religion such as economic disparity, social dislocation, political misrepresentation and the like. ${ }^{15}$ In other

14 "Fikroh Hizbut Tahrir: Hadlarah dan Madaniyah", http:/ /www.hizbut-tahrir. or.id (accessed: 3 December 2012).

${ }^{15}$ Olivier Roy, Globalised Islam: The Search for a New Ummah (London: Hurst, 2004). 
words, ideology only serves as a mass-mobilizing factor that escalates radicalization level of religious understanding. It is the actor factor, i.e., the ideologues who make radical Islamist ideology available to their followers.

With regard to the role of ideology in the rise of radical Islamist ideology, the way the Islamists approach and understand religion will determine the extent to which the phenomenon of radicalization of Islam develops. This is so because religion tends to be approached and understood differently among Muslims. In sociological terminology, the reality of diverse understanding of religion is frequently called as multivocality of religion which is easily found in major religions, and Islam is not an exception in this regard. ${ }^{16}$ Those whose religious vision is literal-formalistic have narrow-minded religious understanding, on the other hand progressive and moderate Muslims are open-minded.

In terms of religious doctrine, there are a number of entry-points where Muslims hold diverse religious understanding in line with the tendency or their ideological leaning. ${ }^{17}$ As a result, the rise of different viewpoints on particular religious doctrine is simply unavoidable. Jihad is perhaps among several religious doctrines in Islam whose meaning is contested by Muslims, particularly moderate Muslims on the one hand and puritan or radical Muslims on the other hand. For moderate or progressive Muslims, the word jihad is perceived in its generic terms as serious and full-hearted struggle to gain God's blessing. Whatever deed in which one employs his/her full-heartedness in God's causes, in moderate Muslims' eyes, it can be regarded as jihad.

There are, however, times when the doctrine of jihad is subject to narrow understanding as a holy war against God's enemies, particularly when Muslims are persecuted and driven away from their homeland. For moderate Muslims, jihad at the outset does not have anything to do with war or violence. In reality, a number of wars throughout the history of Muslims were reduced into generic meaning of jibad becoming something merely related to physical entity such as holy war, and not spiritual struggle

${ }^{16}$ Masdar Hilmy, Islamism and Democracy in Indonesia, 30.

${ }^{17}$ Aziz Al-Azmeh, Islams and Modernities (London \& New York: Verso, 1993), p. 1. See also, John L. Esposito, Islam and Politics (Syracuse, NY: Syracuse University Press, 1998). 
to gain God's blessing and consent. ${ }^{18}$

On the other spectrum, there are those who tend to have stringent way of religious understanding, i.e. radical Islamists, who often perceive jihad in physical holy war. To them, the generic and first meaning of jihad is holy war, despite the fact that linguistically speaking it does not mean war-because in Arabic war means harb or ghazw. ${ }^{19}$ Such an understanding is not without reason, particularly when one refers to a particular segment of classical Muslim scholars who argue that the Qur'anic verses of peace had been abrogated by the verses of war. ${ }^{20}$ In this case, the meaning of jihad cannot be associated with anything related to peaceful effort. This is precisely the underpinning belief widespread among radical Islamists in Indonesia with reference to jihad.

One of the possible explanations is relevant to their formal training in learning Islam. It is that they are not well-versed in comparative perspectives of religious discourses in approaching, reading and grasping the meaning of religion. A comparative perspective can be obtained particularly when one is familiar with religious materials from diverse sources of schools of thoughts. As a consequence, when one has only one source of reading, he/she will settle on a stringent perspective of religious belief on particular issue. Another possible explanation has to do with intrinsic nature or in-born psychological character of each individual among radical Islamist group which tends to be black-andwhite in looking at any issue. ${ }^{21}$

As far as the roots of Islamist ideology has been concerned, there is no single explanation as to why and how Islamism has come into existence. Observers point to two main factors for the existence of

${ }^{18}$ See, for instance, Leonard Michael Kroll, History of the Jihad: Islam versus Civilization (Bloomington, Indiana: AuthorHouse, 2005).

${ }^{19}$ Brian R. Farmer, Understanding Radical Islam: Medieval Ideology in the Twenty-First Century (New York: Peter Lang, 2007), 46. See also, Bernard Lewis, The Political Language of Islam (Chicago: University of Chicago Press, 1988), 72-73.

${ }^{20}$ For a more detailed discussion on this issue, see, Wardani, "Kontroversi Penganuliran Ayat-ayat Damai dengan Ayat Pedang dalam Al-Qur'an: Kajian AnalitisKritis", Ph.D. Thesis, Surabaya: IAIN Sunan Ampel Surabaya, 2010.

${ }^{21}$ Devin R. Springer, et. al., Islamic Radicalism and Global Jibad (Washington D.C.: Georgetown University Press, 2009), p. 149. 
the ideology of Islamism; internal and external factors. ${ }^{22}$ The internal factors refer to the struggle of Islamists from within as a result of the decline of Muslim community compared to the advancement of other communities such as western civilization. Furthermore, internal conflicts as well as political decay among Muslim elites have driven Islamists to come to the fore to revive the spirit of Islam. These internal factors, according to Azra, are behind the rise of Islamism in the past. ${ }^{23}$

External factors, on the other hand, refer to the rise of Islamism as a result of external drive such as colonialism, political hegemony of particular nations over Muslim countries and the confiscation of Muslim lands by non-Muslims. One of the most effective ways to deal with the problem of colonialism is to recall the ideology of Islamism by waging holy war against foreign powers. As Dekmejian rightly puts it, "a recurrent pattern of history is the cause-and-effect relationship between social crises and the rise of religious, revolutionary, or revivalist movements which seek to transform the established order to build a new society on the basis of their particular ideological perception". ${ }^{24}$

In the context of post New Order Indonesia, crisis theories, to a large extent, explain the emergence of Islamism. The 1997 economic crisis was deployed by some Islamist ideologues to appeal a wider audience. Hizbut Tahrir Indonesia (HTI), for instance, came to the Indonesia's political stage in the aftermath of the crisis with its celebrated catchphrase "Selamatkan Indonesia dengan Syari'ab" (Save Indonesia with Shari'ah). ${ }^{25}$ By campaigning their ideology into public, Islamists take the best opportunity out of the economic crisis when the State was in the weakest condition. The post New Order is the critical phase for the resurgence of the ideology of Islamism. This is the phase where the Islamists reached the highest level of confidence in the public. Therefore, it is not surprising that Islamist organizations and movements mushroomed rapidly during

${ }^{22}$ Azyumardi Azra, "Contemporary Islamic Militant Movements in Indonesia", Asian Cultural Studies 15 (2006): pp. 1-10.

${ }^{23}$ Ibid.

${ }^{24}$ R. Hrair Dekmejian, Islam in Revolution: Fundamentalism in the Arab World (Syracuse, N.Y.: Syracuse University Press, 1985), p. 25.

${ }^{25}$ Ismail Yusanto, "Selamatkan Indonesia dengan Syari'at", Burhanuddin (ed.), Syari'at Islam: Pandangan Muslim Liberal (Jakarta: Jaringan Islam Liberal in collaboration with The Asia Foundation, 2003), pp. 139-71. 
this phase and enjoyed the highest profile in the consequence of waning authority of the state.

\section{The State Policy of War against Terrorism}

The issue of war against terrorism has not come to the fore until 2001, when terrorists' attack destroyed the World Trade Center in the US. This was the turning point in the international policy of the US and its allies in which changes in the direction and configuration of countries at the global political stage took place. The US international policy, under the President George W. Bush, adopted the "stick and carrot" policy along with the policy of war against terrorism at the global level. This policy allows the US to give rewards to all countries that follow the policy of war against terrorism by giving them certain amount of funds. On the contrary, those countries which are not on the same boat with the US policy will receive punishment. This policy gives remarkable psychological effects to all countries in the world and makes dividing fault-line between the US and its allies and its "enemies" with a well-known phrase, "either you are with us or against us." This policy has been disseminated to all over the world, and Indonesia is not an exception to the adoption of this policy. ${ }^{26}$

In the context of the US war against terrorism, it must be underlined that deradicalization program in Indonesia cannot be dissociated from the state policy of war against terrorism at the global political stage. At the upstream level, the war against terrorism policy is manifested through the enactment of Act No. 15 Year 2003 on the Eradication of Terrorism Crimes. This Act, however, cannot give deterrent effect in barricading Muslims from subscribing to radical Islamist ideology. This Act, however, can be put into effect when violent or terroristic acts have been perpetrated. It means that this Act cannot restrict and prevent the spreading of radical Islamist ideology in this country. The existence of this Act has nevertheless been resisted by some segments of Indonesian Muslims, particularly from the circle of radical Islamists. They base their argument on human rights by arguing that the Act has risked the freedom of religion and belief guaranteed by the Constitution (UUD 1945).

${ }^{26}$ M. Saleem Kidwai, US Policy towards the Muslim World (Maryland: University of America, 2010), p. 14. 
At the downstream level, the state policy of war against terrorism has executed through security approach. This is done so by, among others, the founding of specific security unit called Special Taskforce (Detasemen Khusus) 88 Antiteror acting as the State's response to the first Bali bombing in 2002. The activities of Densus 88 have not been executed until the head of Police Department of Metro Jaya (Jakarta) Inspector General Firman Gani formalized it on 26 August 2004. This taskforce was fostered by the Decree of the Head of Police Department of the Republic of Indonesia No. 30/VI/2003 dated 20 June 2003, to put the Act No. 15 year 2003 on the Eradication of Terrorism Crimes into effect. That Act is widely known as "Anti-Terrorism Act." This special taskforce is reported to have been funded by the US through the the Ministry of Exterior Affairs of the US and under direct training of the instructors of the CIA, FBI, and the US Secret Service. ${ }^{27}$

The putting of this Act No. 15 year 2003 into effect proves to be effective in dealing with terrorist activities. Some 700 terrorists have been arrested in the past decade with 500 of them having been taken into jail. ${ }^{28}$ Nevertheless, most of the security operation carried out by the Densus 88 is in the forms of ambushing and killing. This means that the killing of most terrorists in Indonesia such as Dr. Azhari, Noordin Mohd. Top, Abu Dujana, the Bali Bombing perpetrators and other terrorists has been carried out by this taskforce within the framework of security approach. On the one hand, the rolling of the terrorist groups has to be acknowledged as the achievement of the Densus 88 in dealing with the violent acts perpetrated by terrorists. One of the missions behind the founding of the Densus 88 is to safeguard the security of every citizen in this country.

The practice and adoption of security approach through the Densus 88 invites criticism and controversies, particularly from Islamist activists. They particularly argue against the method used by the taskforce in detaining and ambushing the perpetrators of terrorist acts which is mostly dominated by violence and killing. Most of the targets have even been shot dead, something that is considered excessive and against

27 "Propaganda Terorisme di Indonesia", http:/ / www.eramuslim.com (accessed: 26 November 2012).

28 "Deradikalisasi dan rehabilitasi terorisme," http://www.bbc.co.uk (accessed: 28 November 2012). 
human rights. The security approach performed by the Densus 88 only victimizes Muslim activists who are committed to implementing the "true" Islam and Islamic shariah. ${ }^{29}$ Furthermore, they argue that the Densus 88 represents foreign intervention into internal affairs of the country that can undermine and curtail the power of Islam.

In response to criticisms and controversies, the government seeks another strategy in dealing with the spread of radical Islamist ideology. In order to respond this issue, Badan Nasional Penanggulangan Terorisme (The National Body of Countermeasure of Terrorism/BNPT) was founded in 2010 based on Presidential Decree No. 46 year 2010. Prior to its establishment, terrorism issues were taken care of by a coordination desk called Coordination Desk on the Eradication of Terrorism (Desk Koordinasi Pemberantasan Terorisme)..$^{30}$ The deradicalization project has started formally when the head of BNPT Ansyaad Mbai, signed a Memorandum of Understanding (MoU) with 8 Muslim based organizations on 11 August 2011 to be involved in this project. ${ }^{31}$ BNPT was designed by the government at the upstream level to curb, prevent and counteract the development of radical Islamist ideology which reached momentum during the post New Order era.

In addition to deradicalization program, BNPT forms a forum called Coordination Forum for preventing the spread of radical ideology, and it has already existed in 10 cities. Other efforts to reduce violence have also been done by other non-governmental organizations such as Yayasan Prasasti Perdamaian by involving ex-terrorist prisoners to have culinary business. Noor Huda Ismail, the leader and founder of the foundation, maintains that the ex-terrorist prisoners must have gone through at least 12 months of crisis period after they get out from jail. This foundation is intended to help ex-prisoners to cope with this critical phase. ${ }^{32}$

Nowadays, the government has been preparing a thorough national program of deradicalization. This program, according to Boediono, the

29 "Munarman: Terorisme, BNPT dan Densus 88 untuk Memerangi Islam", http://manhajkita.blogspot.com (accessed: 3 December 2012).

30 "Detasemen Khusus 88 (Anti Teror)", http://www.wikipedia.org (accessed: 25 November 2012).

31 "Proyek Deradikalisasi, Adu Domba Ummat", Sabili, No. 08/XIX.

32 "Cetak biru deradikalisasi nasional", http://www.bbc.co.uk (accessed: 28 November 2012). 
vice-President of the country, has been designed since long time ago. This program will not only focus on law enforcement, but also involve inter-departmental and ministerial partnership. The formulation of the program is mainly motivated by the fact that the existing program of deradicalization does not have far-reaching impact on society as a whole. ${ }^{33}$ The program called "National Program of Counter-Radical Terrorism (Program Nasional Kontra Radikal Terorisme) will involve 24 governmental and non-governmental institutions including the Ministry of Religious Affairs, the Ministry of Education and Culture, the Ministry of Youth and Sport, the Ministry of Social Affairs, military institution (TNI), police department (Kepolisian RI), Indonesian Council of Muslim Scholars (Majelis Ulama Indonesia/MUI), Indonesian Institute of Science (Lembaga Ilmu Pengetahuan Indonesia/LIPI), Nahdlatul Ulama (NU), Muhammadiyah, Lazuardi Birru, and many others. ${ }^{34}$

According to Boediono, Indonesia needs comprehensive programmes in countering the spread of radical ideology. ${ }^{35}$ What all government institutions have done so far, in his opinion, is not sufficient because there is no common and concerted action with agreed targets and goals among these institutions. For the sake of efectivity, he continues to argue, the deradicalization program has to reach all aspects of social life. In line with this need, it is not only BNPT that should bear the responsibility to curb radicalization and terrorism issues. Deradicalization program must be more extensive, involving all ministerial offices and related institutions. The national deradicalization program can benefit the ministerial programs by incorporating it with a counter-ideology that changes the mindset of people to prevent them from subscribing radical ideology.

The answer to the question as to how this program will be effective depends on the commitment devoted by each individuals and institutions involved which needs to be assessed on regular basis. In addition to shared commitment, socio-political circumstances will be definitely another

33 "Deradikalisasi Sebagai Upaya Mencegah Aksi-aksi Terorisme", a column available at http:/ /www.setkab.or.id (accessed: 26 November 2012).

34 "Pemerintah Siapkan Program Deradikalisasi Nasional Atasi Terorisme," http://www.detik.com (accessed: 28 November 2012) .

35 "Cetak biru deradikalisasi nasional", http://www.bbc.co.uk (accessed: 28 November 2012). 
significant factor in making whether or not the program is successful. It is of course unfair to give a judgment on the program which has just begun. Therefore, we need to give sometime to those who are involved in the deradicalization program to put forth every effort of deradicalization.

\section{The Resistance of Radical Islamists to the Deradicalization Program}

The program of deradicalization carried out by the government of Indonesia is not without resistance from Muslim community in general and the radical Islamists in particular. It is within this respect that the politics of retaliation among radical Islamists can be analyzed. The retaliation basically takes two forms; peaceful agitation and violent acts. What the MUI Surakarta has done by launching a white book is a peaceful effort to argue against deradicalization program. The same case is in the widespread writings and articles found either online or offline concerning the objection and disagreement with deradicalization program launched by the government.

As reported, MUI Surakarta branch has even resisted deradicalization program by arguing that the program serves only as shallowing the faith (akidab) in Islam that can further weaken syari'ah and undermine the unity of Muslim community (ummab). This statement was asserted publicly by Abu Rusydan, an Islamist activist was once arrested by the Densus 88 with terrorist charge, along with book launching entitled "Kritik Evaluasi dan Dekonstruksi Gerakan Dradikalisasi Akidah Muslimin Indonesia" (Critical Evaluation and Deconstruction of the Deradicalization Movement of Muslims' Faith in Indonesia) held by MUI Surakarta (Solo) at the mosque Baitul Makmur in that city, 31 July 2011.36

The book is designed as a response towards the government's

${ }^{36}$ See, www.voa-islam.com (accessed: 17 January 2012). In addition to be held at the mosque Baitul Makmur Surakarta, the book review entitled "Kritik Evaluasi \& Dekonstruksi Gerakan Deradikalisasi Aqidah Muslimin di Indonesia" has been held in some other places, such as Universitas Muhammadiyah Surakarta (UMS) on 31 July 2011 and in the hall of building Mu'allimin Muhammadiyah Yogyakarta on 23 October 2011 which was held by Majlis Tabligh Pimpinan Wilayah Muhammadiyah Daerah Istimewa Yogyakarta. See, http://muhammadiyahdiy.or.id/opini/baca/26/ kritik_evalusi_dan_dekonstruksi_gerakan_deradikalisasi_aqidah_muslim_di_indonesia_ (accessed: 18 January 2012). 
policy regarding the war against terrorism and the deradicalization program. In this context, MUI branch Solo is the only branch among all MUI branches in Indonesia that gave quick response to the government's policy of deradicalization. In that event, the head of MUI Prof. Dr. Zainal Arifin Adnan regarded that the argument crafted along with the deradicalization project is a form of misappropriation (penyelewengan) of the Qur'anic verses and the Prophet's sayings that can jeopardize the fundamental belief of Islam. ${ }^{37}$ The 128-page book sheds a critical light on round-table conference (balaqah) held by MUI Central in collaboration with the Forum for Communication of National Media Practitioners (Forum Komunikasi Praktisi Media Nasional/FKPMN) in 2010, in which the speakers came from the National Body of War against Terrorism (Badan Nasional Penanggulangan terorisme/BNPT). Even though the book was advised by the National MUI be withdrawn from publication, MUI Surakarta stayed in a firm position to resist from deradicalization project by BNPT in conjunction with other Muslim organizations. ${ }^{38}$ The MUI Central's advice undoubtedly invites polemics between the two with regard to deradicalization project promoted by the government. On the one hand, MUI Central serves as the partner of government (through BNPT) in dealing with terrorism. This deradicalization project, however, has been deflated (digembosi) by MUI branch Surakarta.

Apart from that, five Muslim based organizations held a meeting in Cipanas, West Java, on 18 December 2011 to formulate a resistance against the deradicalization program by the government. Those organizations are Abu Bakar Ba'asyir-led Jamaah Anshorut Tauhid (JAT), the Movement of Islamic Reformation (Gerakan Reformasi Islam/Garis), the Defender Front of Islam (Front Pembela Islam/FPI), the Islamic Community Forum (Forum Ummat Islam/FUI), and the Indonesian Council of Mujahidin (Majlis Mujahidin Indonesia/MMI). ${ }^{39}$ Six recommendations were formulated from this forum, one of which is resistance against the

${ }^{37}$ See, www.suaklanjut.com (accessed: 17 January 2012).

38 "MUI Pusat Minta Buku “Gerakan Deradikalisasi” ditarik" (http:// nahimunkar. com/9937/mui-pusat-minta-buku- $\%$ E2\%80\%9Cgerakan-deradikalisasi $\%$ E2\%80\%9Dditarik/ (accessed: 18 January 2012).

${ }^{39}$ See, "5 Ormas Islam Tolak Proyek Deradikalisasi Eks Teroris," Detiknews, (http://www.detiknews.com/read/2011/12/19/100222/1794200/10/5-ormas-islamtolak-proyek-deradikalisasi-eks-teroris) (accessed: 18 January 2012). 
deradicalization program by the government and call for the liquidation of Densus 88 Antiteror. They argue that there is a systematic effort to shallow the fundamental belief of Islam, to divide Muslim community and weaken Islamic movements. They also believe deradicalization program as another type of colonialism on Islam. ${ }^{40}$

This forum was designed as a response towards all government's policies and measures of deradicalization program done by BNPT or all ex-terrorism charged prisoners. It was said that BNPT had prepared a fairly large area in West Java as the potential headquarter for the deradicalization program. Among religious elites who attended that forum were H. Chep Hermawan from Garis, Munarman and Sobri Lubis from FPI, M. Khaththath from FUI, Akhmad Michdan and Son Hadi from JAT, and Abu Rois from MMI. According to Son Hadi from JAT, the forum was attended by no less than 200 people from five Muslim organizations.

Abu Bakar Ba'asyir, in response to the security approach taken by the government, asserts that what the Densus 88 has been fighting is not the terrorists, but the Muslim holy warriors (mujahidin) who are dedicated their life to defend Islam and to resolve the agony of Muslims from the repression of America the Pharaoh, Australia and its allies. He further asserts that:

The Densus 88 has a special anti-bombing military taskforce dominated by Christian police under the command of Gories Mere. Its establishment and the operationalization is funded by America the Pharaoh and Australia. Therefore, the Densus 88 is the tool of America the Pharaoh and Australia whose mission is to fight against and to slaughter the Muslim warriors who uphold the implementation of Islamic shari'ah and protect the Muslim warriors of Indonesia with dirty fabrication (rekayasa kotor) who label them as terrorists. ${ }^{41}$

Ba'asyir further describes the method used by the Densus 88 in investigating or interrogating the accused terrorists as extremely cruel and brutal. He argues that the Densus 88 will use whatever method to force the terrorists to speak up and make testimony under pressure, even

${ }^{40}$ Ibid.

${ }^{41}$ Abu Bakar Ba'asyir, Seruan Taubid di bawah Ancaman Mati (Sukoharjo: JAT Media Center, 2011), p. 19. 
though it is against human rights principles. He said that the three Bali Bomber, Imam Muhlas, Amrozi and Imam Samudra_-whom he calls as mujahid — were forced and tortured in order to sign the BAP (Berita Acara Pidana) prepared by the police with the content of acknowledgement that the first Bali Bombing is under Ba'asyir's instruction. Ba'asyir also claimed that the dirty and fierce method used by the Densus 88 includes making the terrorists naked, forcing them one of them to do sodomy to the other. ${ }^{42}$

A far harsher criticism was given by Ismail Yusanto, the spokesman of the Hizbut Tahrir Indonesia (HTI), in response to the program of deradicalization which he sees to go along with deislamization process. In his opinion, the project costs IDR 400 billion which is inseparable from the project of war against terrorism launched by the US and its allies. ${ }^{43}$ That amount of money, he further maintains, derived from Rand Corporation. BNPT is regarded as a part of the US's grand mission of war against terrorism that will undermine and destroy Islam from within. To him, the core of the problem does not have to do with Islamic doctrine such as jihad, syari'ah, but justice. That is, inequality in every aspect of life between Muslims and the West. As long as global injustice afflicted the Muslim world is not properly addressed, deradicalization policy and program will not work. The measure to terrorism, Ismail continues to argue, necessitates independence in politics. He says that many countries succeed in overcoming crime and security issues without the involvement of the US.44

A more subtle-academic resistance comes from Harits Abu Ulya, the analyst of counter-terrorism and leader CIIA-The Community of Ideological Islamic Analyst, arguing that are two major defects behind the deradicalization project carried out by BNPT. ${ }^{45}$ The first defect concerns what he calls as paradigmatic defect. According to Harits, when the BNPT

${ }^{42}$ Ibid., 20.

43 "Ismail Yusanto: Deradikalisasi mengarah Deislamisasi", Arrabmah (http:// arrahmah.com/read/2011/12/23/16989-ismail-yusanto-deradikalisasi-mengarahdeislamisasi.html), diakses 18 Januari 2012.

${ }^{44}$ Ibid.

${ }^{45}$ Harits Abu Ulya, "Proyek Deradikalisasi BNPT Kenapa Ditolak?”, Eramuslim (http://www.eramuslim.com/berita/analisa/proyek-deradikalisasi-bnpt-kenapa-ditolak. htm), diakses 18 Januari 2012. 
realises that the roots (upstream) of terrorism is the ideology of radical Islamism held by particular segment of Muslim society, the BNPT is committed to "over-simplification" to the real complex problem. In his argument, religion cannot be singled out as the only determining factor behind the rise of terroristic acts, due to factors outside religion have also played significant role such as poverty (economic factor), dislocation, marginalization and gap (social factor), injustice as well as the hegemony of the US on the stage of global politics. He further maintains that:

When BNPT posits that the roots (upstream) of terrorism is the ideology of radicalism (radical Islamist groups), they are oversimplifying the issue at work. As if it is true that the radical ideology is the embryo of terrorism in this country. On the other hand, if we wish to be honest and objective, there other actual factors that contribute to, and have a positive correlation with, the emergence of "terrorism." Those factors are; poverty (economy), backwardness (education), marginalization (social), the repressive attitude of democratic regime which tends to neglect public affairs, globalization, injustice and the last is the imperialism and domination of the US and its allies. ${ }^{46}$

The second defect of the BNPT is the deviation (tabrif) and misdirection (tadথlii) due to new interpretation to the sacred texts in Islam. Theological construct of the BNPT on particular concepts based on which the radical Islamist ideology comes into existence is also deviation of religious doctrine. The religious doctrines constructed by BNPT are, among others: (1) jihhad (holy war), istishhad (martyrdom), ightiyalat (abrupt killing operation) and intibar (suicide bombing); (2) truth claim; (3) commanding good and forbidding wrong (amar ma'ruf nabi munkar); (4) migration (bijrab); (5) devil (taghut); (6) Muslim and infidelity (kufr); (7) middle-path community (ummatan wasatan); (8) conspiracy theory; (9) tolerance (tasamub); (10) state (dawlah) and Islamic caliphate (khilafah Islamiyah). ${ }^{47}$

The meaning of jihad, by the BNPT for instance, which is transformed from "qital" to "ijtibad" is considered as narrowing the real meaning of jihad. Such a reconstruction of jihad is considered "illicit", i.e. against the law of syari'ah. It is also the case when BNPT interprets
${ }^{46}$ Ibid.
${ }^{47}$ Ibid. 
the concept of Dawlah and Kbilafah Islamiyah. Harits maintains that the deconstruction of the two concepts has been done through what he calls as "monsterization" (monsterisasi) and criminalization (kriminalisasi) ${ }^{48} \mathrm{On}$ the contrary, the terminology "Islam rabmatan li al-alamin" constructed by BNPT is assumed to have been built on fragile theological basis. This is what Harits calls as deviation (penyimpangan/tahrif) and misdirection (penyesatan/tadilii).

The explanation above underlines the fact that the deradicalization program carried out by the government of Indonesia has not been responded positively to by some Muslim communities. Among the circle of Muslim hardliners, the degree of resistance has been harsher. There are some reasons why the deradicalization program has not touched public empathy. The first and foremost reason is that the program is perceived by many as "project as usual" from which particular people ca take benefit. ${ }^{49}$ In other words, the program is understood as a part of material commodity among certain elites. It is indeed difficult to deny the fact that there are many cases where the government's program has been associated with the logics of "project as usual," contested by those who harbour interests. The multiplier effect is that the involvement of particular segments into projects have left controversies and debates in the public sphere. The point is that there is disillusionment among those who are left out in these projects.

The second is the government inconsistencies in executing the policies oriented to prosper the wider community and overcoming all problems facing wider society. ${ }^{50}$ While the government showing alert and decisive in responding terrorism issues, but indecisive in dealing with the problem of corruption, stealing public funding. On the other hand, wider community feels that their rights are ignored. Problems inflicted Indonesia such as poverty, unemployment, the rise of price, health, and the like deserve more attention. This means that there is problem of service delivery from the state to society.

The third reason is the excessive use of violence by the Densus 88

${ }^{48}$ Ibid.

49 "Isu Teroris Merupakan Proyek Besar untuk Meraup Dana dari Amerika", http://manhajkita.blogspot.com (accessed: 2 December 2012).

50 "Ada Apa dibalik Kampanye Ansyaad Mbai tentang Ideologi Radikal?", http:// manhajkita.blogspot.com (accessed: 2 December 2012). 
in ambushing the targeted groups or individuals identified as terrorist. ${ }^{51}$ In many cases, instead of sparing the hunted terrorists, therefore can be utilized as a source of information for the purpose of investigation, the members of Densus 88 do not hesitate to shot to death the terrorists. This has been criticized by many, especially by the radical Islamists, as a form of human rights violation, because such a way can be done within the capacity of Densus 88 to arrest them alive. By shooting them dead, the police cannot trace further information about the terrorists' link and their underground activities. This strategy, according to some analysts, will not benefit the whole policies of deradicalization project. Furthermore, this strategy can lead to counter-productive because it can produce further multiplier effects among radical Islamists such as hatred towards the government and police officers.

\section{E. The Use of Violence}

The second form of retaliation is by means of violence. This is particularly committed by some frustrated Islamist youngsters who cannot find any elegant and peaceful solution to resist from deradicalization project or policy of war against terrorism. The violence itself reflects the anger and hatred against what they perceived as "far" and "near" enemies. There have been series of violent acts perpetrated by terrorists as retaliation. The "far" enemies refer to nations or countries-definitely non-Muslim majority ones - that are identified by Islamists to be on the same boat with the US and its allies in the global policy of war against terrorism. This 'far' enemies refer to countries that invade and oppress Muslims such as Israel that expulses the Palestinians out of their homelands. These include also the nations or countries that allowed the insult on venerated figures in Islam, such as the Prophet Muhammad, happened. Denmark and French are of the countries. Meanwhile, the "near" enemies are the figures, individuals or institutions that are in support of the foreign powers in undermining Islam or Muslims. The police department, the government, and or anti-terrorism institutions that support the international policy of war against terrorism are identified

51 "Densus 88 AT Anti Terror dan Pelindung Koruptor", http://densus88at. blogspot.com (accessed: 2 December 2012). 
as the "near" enemy. ${ }^{52}$

The majority of violent acts have direct link to one another even though some do not. For example, the suicide bombers in the Protestant church Gereja Bethel Indonesia Sepenuh (GBIS) Solo, September 25, 2011, are of the Islamist link of Cirebon. ${ }^{53}$ Likewise, the suicide bomber of the mosque Al-Dzikra at the police headquarter in Cirebon is assumed by BNPT to have a direct link with the terrorist group identified in Aceh. ${ }^{54}$ This terrorist group was found in 2012 to have conducted military training in Aceh and was involved in CIMB Niaga bank robbery and bookbombing terror. In a Ba'asyir's plea along with his trial he defended what the terrorists commited in Aceh by arguing that they did preparation (idad) for holy war against God's enemies. For him, they are not terrorists but holy warriors. He further argues that I'dad is obligatory for every Muslim just like five daily prayers, almsgiving, doing pilgrimage and the like. ${ }^{55}$

In regard with the 'near' enemies, it is reported that during March 2011 a series of bombing terror was launched by Pepi Fernando through sending book-bomb to several elites such as Jaringan Islam Liberal (Liberal Islam Network/JIL) activist Ulil Abshar-Abdalla, the Head of National Narcotics Institution Police Department of Indonesia the General Police Gories Mere, and a Jewish-blooded musician Ahmad Dhani. The police have arrested 16 people from these cases and brought them to trial. They received varied sentence from lifetime sentence to 4-year prison. A similar bomb material found exploded in a house complex in Wisata Cibubur, not far from the house of President Susilo Bambang Yudhoyono. ${ }^{56}$ From the trial processes it was found that the book-bombing terror was created as a part of retaliation to what the government has done to Islam and what they perceived as mujahid. They

${ }^{52}$ For further information on the use of "near" and "far" enemies by the radical Islamists, see, for instance, Peter Mandaville, Global Political Islam (New York: Routledge, 2007), 253-62. See, also, Devin R. Springer, et. al., Islamic Radicalism and Global Jihad, 68.

53 “Densus 88 Antiteror Tangkap DPO Jaringan Teroris Cirebon," http://www. voaindonesia.com (accessed: 23 November 2012).

54 “Bom Cirebon Disinyalir Terkait dengan Jaringan Aceh", http:/ /www.tempo. co/read/fokus/2011/04/18/1842/Bom-Cirebon-Disinyalir-Terkait-dengan-JaringanAceh (accesses: 23 November 2012).

${ }_{55}$ Abu Bakar Ba'asyir, Seruan Taubid, pp. 144-45.

56 "Bom Meledak Dekat Rumah SBY", http://www.haluankepri.com (accessed 22 November 2012). 
identified the target of terror as near enemies and they felt obliged to do something as moral responsibility to God by fighting against the enemies.

The latest terror as form of retaliation is the shooting of a police officer in a police station in Solo (30 August 2012). It is reported that a police was shot dead by two unidentified motor cyclists. During that month there were at least two violent threats from unidentified terrorists by grenade toss over public places in that city. The first one was on 17 August 2012, precisely on the Independence Day of the country, and the second attack is on the day after (18 August 2012). ${ }^{57}$ The selection of the day on the Independence Day is not without reason. The Independence Day symbolizes an acknowledgement of national attribute which is, according to the Islamists' ideology, in conflict with the idea of Islamic State (al-Dawlah al-Islamiyah). In Islam, radical Islamists argue, such a kind of attitude can be classified as polytheistic (shirk), one among great sins forbidden in Islam.

One of the most striking facts about radical Islamism in Indonesia is the relationship between West Java and jihadist. According the BNPT's record, 9 out of 12 suicide bombers in Indonesia are from West Java. In Ansyaad Mbai's analysis, the head of BNPT, it has to do with long history of Islamists' resistance in this province against the construct of the state which is considered un-Islamic in nature. As history has recorded, West Java is a home-base for the resistance of Kartosoewirjo-led Negara Islam Indonesia (the Islamic State of Indonesia/NII). In addition, the suicide bomber in Gereja Sepenuh Solo is from Cirebon, West Java. Likewise, the police shooters also came from from West Java.

In regard to the relationship between West Java and Islamist activism, a research project conducted by Lazuardi Birru, a non-profit NGO in conflict and reconciliation affairs, found that West Java has the highest index of volatility towards socio-religious radicalism, i.e., 46.6 percent, with Nanggroe Aceh Darussalam with 43.6 percent placed the second. Furthermore, the index of Jihadism in this province is 47.6 percent, higher than the same index at the national level, which is 46.2. That scale is far higher than the safe threshold index which is 33.3. ${ }^{58}$ This

57 "Teroris Solo Sempat Latihan Militer di Gunung Merbabu", http://www. kompas.com (accessed: 22 November 2012).

58 "Pelaku Bom Manusia Banyak dari Jawa Barat," http://wwwlazuardibirru. org (accessed: 24 November 2012). 
means that West Java has the most likelihood of religious conflict and violence compared to other provinces in the country.

According to information given by Ansyaad Mbai, more than 100 Islamists are involved in the underground Islamist movement, but the government can do nothing to carry out necessary and immediate measures such as capturing them due to constitutional constraint. ${ }^{59}$ The government can conduct immediate measure to only 15 of them under legal basis. The existing constitution guarantees anyone in this country to subscribe to any ideology, including Islamism. As long as it is believed to be manifested in a peaceful manner, the subscription to Islamist ideology is legal. The government cannot interfere such ideology, unless he/ she puts the Islamist ideology into action, such as bombing or crimes. This means that there must be a legal basis to capture radical Islamists. Otherwise, the government will receive a harsh criticisms and backlash from Islamists.

Another fact is the relationship between Ngruki and terrorism. Abu Bakar Ba'asyir's boarding school Al-Mukmin Ngruki-popularly known as Pesantren Ngruki-is notoriously assumed to have a close relationship with the ideology of radical Islamism in Indonesia. ${ }^{60}$ Pesantren Ngruki has special place in the discourse of radical Islamism in the country since the first Bali Bombing in 2001 because some of the perpetrators are the graduates of this pesantren such Amrozi and Ali Imron. The police shooter, Bayu Setiono, is also a droped-out student of this pesantren. In his operation, he was supported by another five friends - three of whom are known as Firman, Farchan, Muchsin—also graduates of Pesantren Ngruki. In ICG's terms, the relationship between radical Islamists and Pesantren Ngruki forms what is called as "Ngruki Network." 1

Despite this network, no immediate measures by the government have been used in response to anticipating the possibilities of terrorist retaliation in the future. Unlike Malaysia in which the state can take immediate actions to the suspected terrorists under the help of Internal Security Act (ISA), Indonesia is traumatized by the use of subversive Act

59 http://www.voaindonesia.com (accessed: 24 November 2012).

${ }^{60}$ See, for instance, International Crisis Group (ICG), Al-Qaeda in Southeast Asia: The Case of the "Ngruki Network" in Indonesia (Jakarta/Brussels: International Crisis Group, December 2002).

${ }^{61}$ Ibid. 
during the New Order regime which has invited wide criticisms from the public. Thanks to ISA, Malaysia has executed a series of decisive policies in dealing with the radical Islamist ideology by, among others, closing down the Islamic boarding school Luqmanul Hakim suspected of being the hot-bet for radical Islamist ideology (Jama'ah Islamiyah/JI). ${ }^{62}$ An opposite condition is the case for Indonesia where the government cannot execute decisive policies towards radical Islamist individuals and groups.

The main purpose of their terrorist acts is to deliver message of resistance against what is perceived as the enemies of God. ${ }^{63}$ Their terrorist acts do not necessarily victimize the target of operation. As long as the message is delivered and understood by the target, the mission is considered successful. Through the message, the Islamists wish to confirm their existence in front of their enemies. They want all of their enemies to take their existence into account in order to be treated reasonably. This is a part of their strategy to persuade the concerned individuals and institutions not to treat them unjustly. By doing so, they have done two things at once; they protect themselves from unjust treatment of the government and protect Islam from the government's arbitrary actions.

\section{E. Conclusion}

What can be summarized from the explanation above is the fact that close and careful scrutiny must be employed in understanding the complex reality of radical Islamism in Indonesia. As this paper has demonstrated, the ideology of radical Islamism and terrorism comprises multifaceted entity that necessitates more thorough approach to cope with. Therefore, it must be admitted from the outset that there is no single monolithic approach that can answers the complex issue of radical Islamism. As a result, there is no single policy to deradicalize Islamist ideology. Once the complex reality of radical Islamism is misunderstood, it can lead to maltreatment of Islamists, which can be fatal for the betterment of socio-political life of the country.

62 "Dahsyatnya 'Dendam' Noordin: Menelusuri Jejak Aktivis JI di Malaysia", http://www.hariansumutpos.com (Accessed: 5December 2012).

63 "Bom Buku Hanya Sebuah Pesan Perlawanan", http://news.detik.com (accessed: 3 December 2012). 
Indonesia is not an exception to this complexity. The security approach adopted by the government in dealing with the Islamist ideology proves to have invited controversies, criticisms, and even resistance from Islamists in general. The Islamists mainly object with the violent method employed by the Densus 88 in ambushing and shooting the radical jihadists to death. In this context, it must be understood that killing Islamists or terrorists will not terminate the spread of radical Islamist ideology. Such a method can even exacerbate civilized and peaceful efforts to deal with the ideology of Islamism or terrorism.

The resistance of Islamists can take two forms; peaceful and violent. In so far as the resistance is concerned, the peaceful method will give benefit to socio-political dynamics of the country. Criticisms can even make democracy better and healthier. But this can be maintained as long as the State does not adopt inappropriate measures or policies with regard to overcoming the ideology of radical Islamism or terrorism. Violent resistance, however, can be counterproductive in the life of society and the reputation of Indonesia at the international level. This is so because such a resistance can result in multiplier effects that drive the politics of retaliation from the radical Islamists and can be even more intense and complicated to deal with. Furthermore, it must be underlined that the state repression to Islamists can swing the pendulum of moderate Muslims' sympathy to their side, in which the death execution of terrorists can generate more terrorists. In addition, the adoption of the security approach does not guarantee the termination of radical Islamist ideology.

It is within the above context that deradicalization efforts need to be proportionately executed. Treating radical Islamism as a complex issue necessitates an understanding that it needs more thorough solution than what the government has implemented so far. Nevertheless, the more thorough approach afforded by the government in deradicalizing the Islamist ideology must be appreciated as a stepping stone in finding a more workable solution to the problem within both short-term and long-term period. The achievement of this program must be evaluated on regular basis.

Put differently, dealing with the ideology of radical Islamism and terrorism must, therefore, cover two poles at once; at the upstream and at the downstream levels. At the upstream level, the program 
of deradicalization must be carried out within the framework of interdepartmental and ministerial partnership. This program must involve as many institutions and has to reach as wide audience as possible. At the downstream level, the program of deradicalization must be placed within the framework of human rights principles. This means that security approach taken by the government will not have to end the threat with killing or dehumanizing effects on Islamists or terrorists. By doing so, the deradicalization program can be productive as well as morally and politically accountable. 


\section{BIBLIOGRAPHY}

Abas, Nasir, Membongkar Jamaah Islamiyah: Pengakuan Mantan Anggota JI, Jakarta: Grafindo, 2005.

Arjomand, Said Amir (ed.), From Nationalism to Revolutionary Islam, Albany, N.Y.: State University of New York Press, 1984.

Ayubi, Nazih, Political Islam: Religion and Politics in the Arab World, London: Routledge, 2004.

Al-Azmeh, Aziz, Islams and Modernities, London \& New York: Verso, 1993.

Azra, Azyumardi, "Contemporary Islamic Militant Movements in Indonesia", Asian Cultural Studies 15, 2006, 1-10.

Ba'asyir, Abu Bakar, Seruan Taubid di bawah Ancaman Mati, Sukoharjo: JAT Media Center, 2011.

van Bruinessen, Martin, "Genealogies of Islamic radicalism in postSuharto Indonesia", South East Asia Research Vol. 10, No. 2, 2002.

Davis, Eric, "Ideology, Social Class, and Islamic Radicalism in Modern Egypt," in Said Amir Arjomand (ed.), From Nationalism to Revolutionary Islam, London: The Macmillan Press, Ltd., 1984.

Dekmejian, R. Hrair, Islam in Revolution: Fundamentalism in the Arab World, Syracuse, N.Y.: Syracuse University Press, 1985.

Esposito, John L., Islam and Politics, Syracuse, NY: Syracuse University Press, 1998.

Farmer, Brian F., Understanding Radical Islam: Medieval Ideologi in the Twentieth Century, New York: Peter Lang, 2007.

Ghadbian, Najib, "Political Islam and Violence," New Political Science, Vol. 22, No. 1, 2000, 77-88.

Hilmy, Masdar, Islamism and Democracy in Indonesia: Piety and Pragmatism, Singapore: ISEAS, 2010.

International Crisis Group (ICG), Al-Qaeda in Southeast Asia: The Case of the "Ngruki Network" in Indonesia, Jakarta/Brussels: International Crisis Group, December 2000.

Kidwai, M. Saleem, US Policy towards the Muslim World, Maryland: University of America, 2010. 
Kolig, Erich, "Radical Islam, Islamic Fervour, and Political Sentiments in Central Java, Indonesia," European Journal of East Asian Studies 4, No. 1, 2005, 55-86.

Kroll, Leonard Michael, History of the Jihad: Islam versus Civilization, Bloomington, Indiana: AuthorHouse, 2005.

Lakoff, Sanford, "The Reality of Muslim Exceptionalism," Journal of Democracy, Vol. 15, No. 4/Oct, 2004.

Lewis, Bernard, The Political Language of Islam, Chicago: University of Chicago Press, 1988.

Mandaville, Peter, Global Political Islam, New York: Routledge, 2007.

Roy, Olivier, Globalised Islam: The Search for a New Ummah, London: Hurst, 2004.

Shepard, William E. Shepard, "Islam and Ideology: Towards a Typology," International Journal of Middle East Studies, Vol. 19, No. 3, Aug., 1987.

Sivan, Emmanuel, "The Enclave Culture," in Martin E. Marty \& Scott Appleby (eds.), Fundamentalisms Comprehended, Chicago: University of Chicago Press, 2004.

Springer, Devin R. (et. al.), Islamic Radicalism and Global Jihad, Washington D.C.: Georgetown University Press, 2009.

Wardani, "Kontroversi Penganuliran Ayat-ayat Damai dengan Ayat Pedang dalam Al-Qur'an: Kajian Analitis-Kritis", Surabaya: Ph.D. Thesis, IAIN Sunan Ampel Surabaya, 2010.

Yusanto, Ismail, "Selamatkan Indonesia dengan Syari'at", in Burhanuddin (ed.), Syari'at Islam: Pandangan Muslim Liberal, Jakarta: Jaringan Islam Liberal in collaboration with The Asia Foundation, 2003. 